\title{
KESANTUNAN BERBAHASA DI SMA NEGERI I DULUPI \\ KABUPATEN BOALEMO DAN IMPLEMENTASINYA DALAM PEMBELAJARAN
}

\author{
Sri Yulianti Lahabu, Dakia DjoU, Muslimin \\ Prodi Pendidikan Bahasa Indonesia, Pascasarjana Universitas Negeri Gorontalo
}

\begin{abstract}
ABSTRAK
Tujuan penelitian adalah (1) mendeskripsikan bentuk kesantunan berbahasa di SMA Negeri I Dulupi Kabupaten Boalemo, (2) mendeskripsikan faktor-faktor yang mendukung kesantunan berbahasa di SMA Negeri I Dulupi Kabupaten Boalemo, (3) mendeskripsikan implementasi kesantunan berbahasa dalam pembelajaran di SMA Negeri I Dulupi. Metode penelitian yang digunakan adalah metode deskriptif kualitatif dengan sumber data berupa tuturan yang terjadi selama pembelajaran bahasa Indonesia serta tuturan di luar pembelajaran di SMA Negeri I Dulupi Kabupaten Boalemo. Teknik sampling penelitian ini menggunakan teknik simak, teknik rekaman, teknik catat, wawancara, dan observasi. Teknik uji data yang digunakan yaitu triangulasi sumber data dan triangulasi teori. Hasil penelitian ini menunjukkan bahwa (1) terdapat enam bentuk kesantunan berbahasa di SMA Negeri 1 Dulupi Kabupaten Boalemo berdasarkan prinsip maksim kesantunan, yaitu: (a) maksim kebijaksanaan, (b) maksim kedermawanan, (c) maksim penghargaan, (d) maksim kesederhanaan, (e) maksim pemufakatan, dan (f) maksim kesimpatian, dan terdapat tiga pelanggaran maksim menurut prinsip kesantunan berbahasa, yaitu: (a) maksim kebijaksanaan, (b) maksim kedermawanan, dan (c) maksim kesederhanaan; (2) Ditemukan faktor-faktor yang mendukung kesantunan, berupa: (a) meminta dan memohon kepada mitra tutur tanpa paksaan dan tidak menyinggung, (b) mempersilakan mitra tutur tanpa paksaan dan (c) tidak menyinggung; serta (d) memberikan tanggapan positif terhadap mitra tutur, dan ditemukan ketidaksantunan, berupa: (a) mengkritik dengan diksi dan intonasi negatif serta tidak bisa mengendalikan emosi; (b) berpendapat dengan menyinggung mitra tutur; dan (c) memotong pembicaraan mitra tutur; (3) Implementasi kesantunan berbahasa diterapkan pada proses pembelajaran bahasa Indonesia dengan memperhatikan prinsip maksim kesantunan berbahasa di SMA Negeri 1 Dulupi, Kabupaten Boalemo
\end{abstract}

Kata kunci: Kesantunan, Berbahasa, Implementasi, Pembelajaran, Peserta Didik

\section{PENDAHULUAN}

Praktik kesantunan berbahasa pada pendidikan formal merupakan tolak ukur bagi generasi bangsa dalam menggunakan bahasa, tidak saja bagi mereka yang memiliki kecerdasan intelektual, akan tetapi generasi bangsa yang memiliki kecerdasan emosional dan spiritual. Kesantunan berbahasa melalui lingkungan pendidikan formal dapat dilakukan pada semua mata pelajaran dan jenjang pendidikan, sehingga guru harus menjadi contoh teladan dalam penggunaan kesantunan berbahasa di sekolah. Interaksi yang terjadi di sekolah merupakan indikator utama dalam praktik kesantunan berbahasa dalam kegiatan pembelajaran dan kegiatan lainnya yang mendukung program di sekolah, yakni antara guru dengan guru, guru dengan siswa, siswa dengan siswa lainnya, dan guru dengan pegawai tata usaha. Tindakan bahasa di sekolah harus sesuai dengan etika yang berlaku di sekolah.

Chaer (2006:1) mengatakan bahasa merupakan suatu sistem lambang berupa bunyi, bersifat arbitrer, digunakan oleh suatu masyarakat tutur untuk bekerja sama, berkomunikasi, dan mengidentifikasi diri. Bahasa sebagai sebuah sistem yang terbentuk oleh suatu aturan, kaidah, atau pola-pola tertentu, baik pada bidang tata bunyi, bentuk kata, maupun bentuk kalimat. Apabila kaidah atau aturan-aturan tersebut terganggu, maka komunikasi pun dapat terganggu pula. Seseorang menyampaikan pikiran, pengalaman, gagasan, pendapat, perasaan, keinginan, harapan kepada sesama manusia tetap menggunakan bahasa. Dengan bahasa itu pula orang dapat mewarisi dan mewariskan, menerima dan menyampaikan segala 
pengalaman dan pengetahuan lahir batin (Poerwadarminta,1984:5).

Bahasa merupakan suatu sistem komunikasi yang menggunakan simbol-simbol vokal (bunyi ujaran) bersifat arbitrer yang dapat diperkuat dengan gerak-gerik badaniah yang nyata, ia merupakan simbol karena rangkaian bunyi yang dihasilkan oleh alat ucap manusia harus diberikan makna tertentu, yaitu mengacu kepada sesuatu yang dapat dicerap panca indra (Keraf, 2004:2). Selanjutnya Chaer (2010:25) menjelaskan kesantunan berbahasa sebagai realisasi penghormatan dari seorang penutur kepada penutur. Kesantunan dan penghormatan adalah dua istilah yang saling berkaitan. Contoh dalam bahasa Jawa, seseorang dianggap santun jika ia menggunakan bentuk hormat kepada yang lebih tua atau yang memiliki kedudukan tingkat tinggi. Kesantunan adalah usaha menunjukkan kesadaran yang berkenaan dengan muka orang lain. Jadi, kesantunan sebagai tindakan melindungi.

Menurut Widjono Hs (2005:10-11) bahasa merupakan sistem lambang bunyi ujaran yang digunakan untuk berkomunikasi oleh masyarakatnya. Bahasa yang baik berkembang berdasarkan sistem yaitu seperangkat aturan yang dipatuhi oleh pemakainya. Sistem tersebut, yaitu: (a) sistem yang bermakna dan dapat dipahami oleh masyarakat pemakainya, (b) sistem lambing bersifat konvensional, (c) lambang-lambang tersebut arbitrer, (d) sistem lambang bersifat terbatas, tetapi produktif, artinya sistem yang sederhana dan jumlah aturan yang terbatas, (e) sistem lambang bersifat unik, khas, dan tidak sama dengan lambang bahasa yang lain, dan (f) sistem lambang dibangun berdasarkan kaidah yang bersifat universal.

Menurut Leech (1993:206) kesantunan berbahasa merupakan bagian terpenting yang perlu diperhatikan bagi pemakai bahasa untuk menciptakan komunikasi yang baik antar pemakai bahasa. Kesantunan berbahasa mencerminkan etika seorang pemakai bahasa. Dalam kesantunan berbahasa perlu diperhatikan prinsip sopan santun. Prinsip sopan santun sebagai bentuk kesantunan dalam berkomunikasi lisan yaitu maksim kearifan, maksim kedermawanan, maksim pujian, maksim kerendahan hati, maksim kesepakatan, dan maksim simpati. Maksim yaitu Maksim/ mak.sim/n pernyataan ringkas yang mengandung ajaran atau kebenaran umum tentang sifat-sifat manusia; aforisme; peribahasa.

Sebuah ungkapan menyebutkan "bahasa mencerminkan kepribadian seseorang". Artinya, dengan bahasa kita dapat menilai karakter seseorang. Jika penggunaan bahasa kita baik dan penuh kesantunan maka pencitraan diri kita pun sebagai pribadi yang baik dan berbudi, sementara itu apabila penggunaan bahasa kita tidak memenuhi etika berbahasa yang santun maka pencitraan diri kita pun menjadi buruk. sehingga kesantunan berbahasa menjadi salah satu tolak ukur pribadi yang berkarakter. Berkaitan dengan itu, mentradisikan kesantunan berbahasa melalui lingkungan pendidikan formal maupun informal merupakan upaya yang harus dilakukan untuk menyiapkan generasi bangsa yang berkarakter. Generasi yang berkarakter diperlukan dalam menghadapi era globalisasi.

Menurut Chaer, Abdul dan Agustina (2004:172) seseorang dikatakan santun apabila ia beretika dan seseorang yang beretika akan santun dalam tindak tanduknya termasuk dalam menggunakan bahasa. Kesantunan berbahasa berkaitan dengan pemilihan kode bahasa, norma-norma sosial, dan sistem budaya yang berlaku dalam suatu masyarakat karena kesantunan berbahasa akan mengatur hal-hal berikut ini. Pertama. Apa yang akan dikatakan pada waktu dan keadaan tertentu kepada seorang partisipan sehubungan dengan status sosial dan budaya dalam masyarakat itu. Kedua. Ragam bahasa apa yang paling wajar digunakan dalam situasi dan budaya tertentu. Ketiga. Kapan dan bagaimana cara seorang pemakai bahasa menggunakan giliran berbicara dan menyela pembicaraan orang lain. Keempat. Kapan seorang pemakai bahasa harus diam. Kelima. Bagaimana kualitas suara dan sikap fisik pemakai bahasa di dalam berbicara. Apabila seorang pemakai bahasa 
memperhatikan hal-hal tersebut maka seorang pemakai bahasa dianggap telah menguasai tata cara atau kesantunan berbicara. Dengan kata lain, seorang pemakai bahasa tersebut telah memperhatikan kesantunan dalam menggunakan bahasa. Sedangkan Setiawan dan Rois (2017:145) mengatakan watak, karakter, atau sifat orang mampu dilihat dari cara memilih bahasa yang diutarakan, sedangkan menurut Hamidah. (2017:65) bahasa yang lembut, santun, sistematis, dan jelas yang digunakan akan mencerminkan budi penutur. Begitu pula sebaliknya, bahasa kasar yang disampaikan penutur akan mencerminkan kepribadian yang tidak berbudi. Dengan demikian, perlu penggunaan bahasa yang disesuaikan dengan konteks, mitra tutur, maupun aturan yang membuat bahasa sebagai alat efektif dalam mengutarakan kehendak.

Pada dasarnya, faktor kesantunan berbahasa secara lisan adalah ketepatan penggunaan intonasi, kuat-lembutnya suara, penggunaan nada, dan penggunaan pilihan kata dalam kalimat dengan menyatakan "Faktor penentu kesantunan berbahasa yaitu segala hal yang dapat memengaruhi pemakaian bahasa menjadi santun atau tidak santun. Faktor penentu kesantunan dalam bahasa verbal lisan antara lain aspek intonasi (keras lembutnya intonasi ketika seseorang berbicara), aspek nada bicara (berkaitan dengan suasana emosi penutur; nada resmi, nada bercanda, nada mengejek, menyindir, dan sebagainya), faktor pilihan kata, dan faktor susunan kalimat.

Djajasudarma (2012:53) menjelaskan bahwa guru sebagai manajer dalam proses belajar mengajar menyampaikan pesan atau informasi tertentu dalam bentuk tuturan. bahwa tindak tutur merupakan sebuah perilaku atau aksi berupa tindakan dengan menggunakan bahasa. Aksi tersebut dapat berupa suruhan, perintah, memberi informasi, memohon, menjanjikan, dan lain-lain. Tindakan tersebut memanfaatkan bahasa untuk menyampaikan maksud atau tujuan dari penutur. Peran guru dalam proses pembelajaran bertujuan agar siswa dapat menunjukkan adanya perkembangan secara positif. Tindak tutur guru dalam pembelajaran sangat penting sebab apa yang diutarakan merupakan keseluruhan instruksi dalam proses pembelajaran. Hal tersebut merujuk pada penggunaan tuturan yang baik dan sesuai konteks dalam kelas agar tercipta suasana belajar yang mengesankan bagi guru dan siswa.

Menurut Sumarsono dan Paina (2002:150) kesantunan berbahasa dapat memberikan unsur positif dalam berbahasa yang menghasilkan kesopanan berbahasa antara guru dengan guru, guru dan siswa serta siswa dan staf pegawai tata usaha. Siswa di SMA Negeri I Dulupi memiliki ciri petualangan, pengelompokan, serta kenakalan. Ciri ini tercermin pula dalam bahasa mereka. kesantunan ketika berbahasa terhadap lawan bicara menjadi tolak ukur untuk menciptakan komunikasi yang baik hal ini sering terjadi di kalangan siswa yang kurang menggunakan kesantunan berbahasa yang baik dan benar, terkadang siswa lebih di pengaruhi budaya lokal yaitu Bahasa Gorontalo dan tak heran banyak siswa menggunakan Bahasa Korea yang tren bagi kalangan siswa.

Menurut Chaer (2010:10) secara singkat dan umum ada tiga kaidah yang harus dipatuhi agar tuturan kita terdengar santun oleh pendengar atau lawan tutur kita. Ketiga kaidah itu adalah 1). formalitas (formality), 2). ketidaktegasan (hesistancy), dan 3) kesamaan atau kesekawanan (equality or camaraderie). Jadi, dengan singkat bisa dikatakan bahwa sebuah tuturan disebut santun kalau ia tidak terdengar memaksa atau angkuh, tuturan itu memberi pilihan tindakan kepada lawan tutur, dan lawan tutur itu menjadi senang.

Kesantunan berbahasa di sekolah menengah khususnya di SMA Negeri I Dulupi Kabupaten Boalemo belum efektif terhadap kesantunan berbahasa baik pada guru terhadap siswa maupun sebaliknya. realisasi kesantunan berbahasa berlatar belakang budaya bahasa Gorontalo sangat tinggi, sehingga penulis ingin mengetahui lebih dalam perihal kesantunan berbahasa di SMA Negeri 1 Dulupi dan Implementasinya dalam Pembelajaran, serta apa saja penanda maksim-maksim kesantunan 
berbahasa baik dalam kegiatan pembelajaran di kelas maupun kesantunan berbahasa di luar kelas. kesantunan berbahasa dapat ditingkatkan melalui pendekatan aktivitas berbahasa di luar kelas karena bebas mengeluarkan pendapat dan bahasa jika dibandingkan di dalam kelas yang terdapat banyak interaksi antara siswa dan guru atau guru dan siswa, sehingga kaidah bahasa banyak dimunculkan karena pada dasarnya hakikat bahasa dapat dikatakan sebagai alat untuk berinteraksi.

Menurut Rahardi (2005:33) mengatakan bahwa sebuah tindak tutur dapat merupakan ancaman terhadap muka. Tindak tutur seperti ini oleh Brwon dan Levinson disebut sebagai Face Threathening Act (FTA). Untuk mengurangi kekerasan ancaman itulah di dalam berkomunikasi kita tidak harus selalu menaati Prinsip Kerja Sama dalam pertuturan.

Beberapa faktor atau hal yang menyebabkan sebuah pertuturan itu menjadi tidak santun. Penyebab ketidaksantunan itu antara lain: (1) Kritik secara langsung dengan kata-kata kasar, (2) kritik kepada lawan tutur secara langsung dan dengan menggunakan kata-kata kasar akan menyebabkan sebuah pertuturan menjadi tidak santun atau jauh dari peringkat kesantunan. Dengan memberikan kritik secara langsung dan menggunakan katakata yang kasar tersebut dapat menyinggung perasaan lawan tutur, sehingga dinilai tidak santun, (3) Dorongan rasa emosi penutur kadang kala ketika bertutur dorongan rasa emosi penutur begitu berlebihan sehingga ada kesan bahwa penutur marah kepada lawan tuturnya. Tuturan yang diungkapkan dengan rasa emosi oleh penuturnya akan dianggap menjadi tuturan yang tidak santun, (4) Protektif terhadap pendapat sering kali ketika bertutur seorang penutur bersifat protektif terhadap pendapatnya. Hal ini dilakukan agar tuturan lawan tutur tidak dipercaya oleh pihak lain. Penutur ingin memperlihatkan pada orang lain bahwa pendapatnya benar, sedangkan pendapat mitra tutur salah. Dengan tuturan seperti itu akan dianggap tidak santun, (5) Sengaja menuduh lawan tutur bahwa acapkali penutur menyampaikan tuduhan pada mitra tutur dalam tuturannya. Tuturannya menjadi tidak santun jika penutur terkesan menyampaikan kecurigaannya terhadap mitra tutur, (6) Sengaja memojokkan mitra tutur. Pertuturan menjadi tidak santun karena penutur dengan sengaja ingin memojokkan lawan tutur dan membuat lawan tutur tidak berdaya. Dengan ini, tuturan yang disampaikan penutur menjadikan lawan tutur tidak dapat melakukan pembelaan (Pranowo (2009:69-71).

Menurut Sugiyono (2007:297) dalam penelitian kualitatif tidak menggunakan populasi, karena penelitian kualitatif berangkat dari kasus tertentu dan hasil kajiannya tidak akan diberlakukan ke populasi, tetapi ditransferkan ke tempat lain pada situasi sosial yang memiliki kesamaan dengan situasi sosial pada kasus yang dipelajari. Sampel dalam penelitian kualitatif bukan dinamakan responden, tetapi sebagai narasumber, atau partisipan, informan, teman dan guru dalam penelitian. Sampel dalam penelitian kualitatif juga bukan disebut sampel statistik, tetapi sampel teoritis, karena tujuan penelitian kualitatif adalah untuk menghasilkan teori. Dari penelitian ini akan diketahui bagaimana kesantunan berbahasa di SMA Negeri I Dulupi Kabupaten Boalemo dan Implementasinya dalam Pembelajaran.

\section{METODE PENELITIAN}

\section{Pendekatan dan Jenis Penelitian}

Penelitian ini merupakan penelitian kualitatif. Secara umum penelitian ini menggunakan metode deskriptif kualitatif dengan teknik analisis isi, yaitu memaparkan hasil penelitian yang diperoleh tentang tuturan pada proses pembelajaran di sekolah dalam skala prinsip kesantunan berbahasa. Metode deskriptif adalah metode paparan hasil temuan berdasarkan fakta yang ada atau fenomena yang diperoleh berdasarkan data yang dikumpulkan dari lapangan.

Penelitian ini menggunakan jenis penelitian kualitatif, karena data yang digunakan sebagai objek dalam penelitian yaitu berupa tuturan kesantunan berbahasa Indonesia. Ciri khas sebuah penelitian 
kualitatif adalah penelitian untuk mendeskripsikan peristiwa, perilaku orang, maupun suatu keadaan pada tempat tertentu secara rinci dalam bentuk narasi.

Moleong (2000:157) mengatakan bahwa sumber data utama dalam penelitian kualitatif ialah kata-kata dan tindakan, selebihnya adalah data tambahan seperti dokumen dan lain-lain. Sumber data dalam penelitian ini berasal dari hasil observasi, rekaman, dan wawancara di lapangan secara langsung dan didokumentasikan dalam transkrip percakapan yang memuat tentang tindak tutur, informasi, situasi, serta kejadian dari responden. Rekaman memuat dokumentasi berupa tuturan dari guru kepada siswa, siswa kepada guru, guru pada pegawai tata usaha, dan beberapa tuturan antar siswa di lingkungan sekolah.

\section{Data dan Sumber Data}

Menurut Sugiyono (2007:300) data kualitatif adalah data yang berbentuk kata-kata , kalimat, skema, gambar, dan tidak berupa angka-angka, yang menyangkut sejarah, struktur organisasi atau hasil wawancara terhadap obyek penelitian berupa jawaban atas pertanyaan yang diberikan. Sumber data dalam penelitian ini adalah: (1) Sumber Data Primer. Data primer yaitu data yang diperoleh langsung dari sumbernya, diamati dan dicatat dalam hal ini data yang dihimpun adalah tentang kesantunan berbahasa di SMA Negeri 1 Dulupi Kabupaten Boalemo. Sumber data dapat diperoleh di antaranya melalui guru dan siswa atau siswa dan guru dan data tersebut berupa jawaban atas pertanyaan-pertanyaan yang diajukan melalui wawancara, (2) Sumber Data Sekunder. Data sekunder adalah data yang diperoleh atau dikumpulkan oleh orang yang melakukan penelitian dari sumber-sumber yang telah ada (Hasan, 2002: 58). Data ini digunakan untuk mendukung informasi primer yang telah diperoleh yaitu dari bahan pustaka, literatur, penelitian terdahulu, buku, Jurnal dan lain sebagainya.

\section{Teknik dan Prosedur Pengumpulan Data}

Untuk mencari atau mengumpulkan data penelitian ini, penulis menggunakan beberapa metode yang terdapat dalam buku Mahsun yang berjudul "Metode Penelitian Bahasa" (2005:242). Teknik pengumpulan data menggunakan pengumpulan data secara kualitatif dengan langkah-langkah sebagai berikut: (1) Teknik Simak. Pengambilan subjek atau cuplikan yang digunakan pada penelitian ini dengan teknik simak. Teknik simak adalah teknik yang digunakan untuk memperoleh data dengan cara menyimak penggunaan bahasa yang dibahasakan oleh guru dan siswa selama berada di lingkungan SMA Negeri I Dulupi Kabupaten Boalemo, (2) Teknik Rekaman. Teknik Rekaman digunakan untuk merekam semua aktivitas siswa, guru, pegawai tata usaha selama berada di lingkungan SMA Negeri I Dulupi Kabupaten Boalemo. Kegiatan perekaman menggunakan alat perekam berupa telepon genggam. Data yang direkam adalah seluruh ujaran atau tuturan dibahasakan oleh guru dan siswa di lingkungan SMA Negeru I Dulupi Kabupaten Boalemo, (3) Teknik catat. Teknik catat digunakan untuk mencatat tuturan yang sedang berlangsung yang di bahasakan oleh guru dan siswa di lingkungan SMA Negeri I Dulupi Kabupaten Boalemo, (4) Wawancara. Wawancara yang dilakukan dengan cara berbicara secara bebas antar siswa dan guru dilingkungan SMA Negeri I Dulupi Kabupaten Boalemo untuk mendapatkan informasi awal tuturan bahasa yang di gunakan, (4) Observasi. Dengan cara melakukan pengamatan terhadap aktivitas siswa, guru, pegawai tata usaha selama berada di lingkungan SMA Negeri I Dulupi Kabupaten Boalemo untuk mengetahui tutur bahasa yang di gunakan.

Prosedur pengumpulan data dilakukan dalam beberapa tahap, yakni tahap pengumpulan data, tahap analisis data, tahap penyajian hasil analisis data. Dalam tahap pengumpulan data, penelitian ini menggunakan metode simak, yakni metode pengumpulan data yang dilakukan dengan menyimak kesantunan berbahasa dari beberapa rekaman pembicaraan siswa dengan siswa, siswa dengan guru, 
dilanjutkan dengan teknik catat, yaitu mencatat atau mentranskripsi rekaman menjadi data tulis. Kemudian transkripsi tulisan itu masingmasing dipasang-pasangkan ujarannya. Data yang terkumpul tersebut kemudian dianalisis berdasarkan teori yang dipakai.

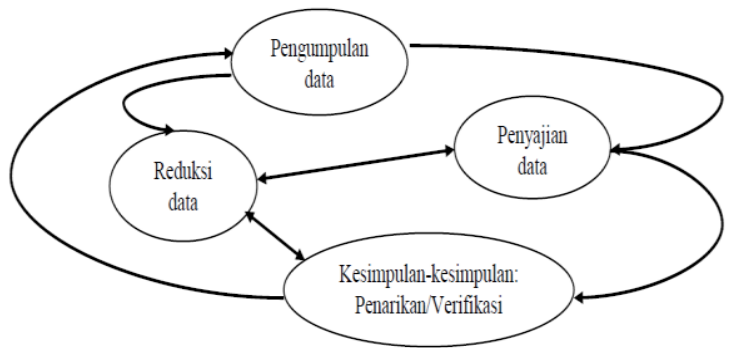

Gambar 1. Komponen-komponen Analisis Data Kualitatif

Berdasarkan Gambar 1, analisis data kualitatif merupakan upaya yang berlanjut, berulang, dan terus menerus. Masalah reduksi data, penyajian data, dan penarikan kesimpulan/verifikasi menjadi gambaran keberhasilan secara berurutan sebagai rangkaian kegiatan analisis yang saling susul menyusul. Namun dua hal lainnya itu senantiasa merupakan bagian dari lapangan.

\section{HASIL DAN PEMBAHASAN}

Data penelitian berupa tuturan yang diperoleh dari Siswa dan Guru di SMA Negeri 1 Dulupi Kabupaten Boalemo. Jumlah data yang dianalisis sebanyak 110 tuturan yang terdiri dari 80 tuturan yang terjadi pada siswa, dan 30 tuturan pada guru. Data dianalisis berdasarkan prinsip kesantunan dengan kaidah kesantunan. Data digolongkan menjadi dua bagian, yaitu bentuk pematuhan prinsip kesantunan berbahasa dan bentuk pelanggaran prinsip kesantunan berbahasa. Kemudian diuraikan pula faktor-faktor yang mendukung kesantunan berbahasa dan implementasinya dalam pembelajaran. Hasil penelitian ini kemudian dideskripsikan secara berurutan berikut ini.

A. Bentuk Kesantunan dalam Prinsip Pematuhan Kesantunan Berbahasa di SMA Negeri 1 Dulupi Kabupaten Boalemo
1. Bentuk kesantunan berbahasa antar siswa di lingkungan sekolah

Santun atau tidaknya suatu tuturan dapat dilihat berdasarkan bentuk kesantunan berbahasa. Terdapat dua bentuk kesantunan yaitu bentuk kesantunan linguistis dan bentuk kesantunan pragmatis. Bentuk kesantunan linguistis terdiri dari intonasi, diksi, dan struktur kalimat sedangkan bentuk kesantunan pragmatis yaitu cara atau gaya bahasa.

Salah satu faktor penentu bentuk kesantunan yaitu penggunaan pilihan kata (diksi) yang tepat sesuai dengan peristiwa tutur dan lawan tutur. Interaksi dengan siswa dalam ragam resmi menggunakan pilihan kata (diksi) yang sesuai dengan situasi pertuturan. Sementara dalam ragam pergaulan, terdapat dua pilihan kata yang digunakan yakni kata "jangan" dan "belum". Kata "jangan" digunakan sebagai larangan. Dalam konteks tuturan di atas, kata "jangan" bukan sekedar larangan tetapi juga memunculkan daya bahasa. Kata "jangan" juga dipersepsi bukan sekedar dari maknanya tetapi melalui daya bahasanya. Kata "jangan" dipersepsi sebagai "larangan sambil menyuruh introspeksi diri”.

Faktor intonasi sangat mempengaruhi kesan lawan tutur terhadap sebuah tuturan. Penutur akan dikatakan santun ketika ia mampu menguasai perasaan, emosi yang ada dalam dirinya ketika berkomunikasi dengan orang lain. Pelafalan yang jelas akan membuat komunikasi berjalan dengan lancar. Begitu pun nada tuturan harus sesuai situasi, topik pembicaraan, lawan tutur, dan jarak. Penutur yang berbicara dengan nada keras padahal lawan tuturnya berada pada jarak yang dekat akan memberikan kesan bahwa penutur tidak dapat berbicara dengan santun. Sebaliknya jika penutur berbicara dengan nada lemah lembut pada lawan tutur yang berada pada jarak yang dekat dengannya maka ia akan dikatakan penutur yang santun.

Penggunaan struktur kalimat yang benar mempengaruhi penilaian lawan tutur 
terhadap sebuah tuturan. Penutur hendaknya menggunakan struktur kalimat yang baik, dapat dipahami dan diterima dengan mudah tanpa menyinggung perasaan lawan tutur.

\section{Bentuk Kesantunan Berbahasa} Siswa dalam Berinteraksi dengan Guru

Penggunaan pilihan kata (diksi)
"beliau", "maaf", "dananya",
"perkenalkan" memiliki kadar yang lebih santun jika dibandingkan dengan kata "dia", "uangnya", dan "beritahukan". Meskipun dalam kata-kata tersebut sering digunakan akan tetapi dalam konteks tuturan tertentu kata-kata tersebut masih dirasa belum mencerminkan kesantunan. Penggunaan kata "beliau" memberikan kesan bahwa penutur sangat menghormati orang yang sedang dibicarakannya.

Tuturan dapat dikatakan santun apabila sesuai dengan konteks tuturannya. Dalam tuturan siswa dengan lawan tuturnya guru, siswa menggunakan intonasi (nada, jeda, tekanan, lafal) yang sesuai. Secara keseluruhan, ketika berinteraksi dengan guru, siswa cenderung menggunakan nada rendah, lafal jelas, tekanan dan jeda yang sesuai dengan tuturan. Hal ini dikarenakan ketika siswa berinteraksi dengan guru, pada dasarnya siswa sudah mengetahui intonasi yang harus digunakan ketika berkomunikasi dengan orang yang dihormati.

Secara keseluruhan, struktur kalimat yang digunakan dalam tuturan siswa dengan guru memperlihatkan penggunaan kalimat yang biasa tidak terlalu memfokuskan kata pada awal kalimat. Bentuk kesantunan berbahasa yang kedua yaitu bentuk kesantunan pragmatis. Bentuk kesantunan pragmatis adalah cara atau gaya bahasa yang digunakan dalam tuturan.

B. Faktor-faktor yang Mempengaruhi Kesantunan Berbahasa Di SMA Negeri I Dulupi Kabupaten Boalemo

Faktor penyebab ketidaksantunan berbahasa terjadi ketika penutur tidak mampu mengendalikan apa yang mereka bicarakan sehingga bahasa yang digunakan menjadi tidak santun. Hal ini sejalan dengan yang disampaikan Pranowo (dalam Chaer, 2010:57) yang menjelaskan beberapa faktor pemakaian bahasa yang tidak santun di antaranya yaitu: 1) menyampaikan kritik secara langsung dengan berkata kasar; 2) emosi pada diri penutur; 3) protektif terhadap pendapat penutur; 4) penutur sengaja memojokkan mitra tutur; 5) menuduh atas dasar kecurigaan terhadap mitra tutur. Faktor yang mempengaruhi kesantunan dalam bertutur dibedakan menjadi dua (Pranowo, 2009:70) yaitu: 1) faktor kebahasaan seperti, intonasi, nada, pilihan kata 2) faktor nonkebahasaan seperti, pranata sosial budaya masyarakat, sikap penutur, topik yang dibicarakan.

Berdasarkan beberapa uraian faktor yang telah disampaikan di atas dapat disimpulkan bahwa faktor yang menyebabkan ketidaksantunan dalam berbahasa yaitu, pertama, faktor internal, meliputi kemampuan berbahasa dan kepribadian yang dimiliki seseorang. Bagaimana pilihan kata, intonasi, nada, cara pengucapan yang digunakan dan lain sebagainya. Selain itu, juga sikap penutur terhadap mitra tutur dan juga gerak geriknya ketika bertutur juga memengaruhi kesantunan bahasa yang digunakan. Kedua, faktor eksternal, meliputi lingkungan keluarga, teman sebaya, lingkungan masyarakat. Keluarga merupakan pendidikan pertama bagi anak untuk meniru apa pun yang diucapkan guru, santun tidaknya bahasa yang digunakan.

\section{Implementasi Kesantunan Berbahasa dalam Pembelajaran di SMA Negeri 1 Dulupi Kabupaten Boalemo}

Pembelajaran adalah proses, perbuatan, cara mengajar atau mengajarkan, atau segala sesuatu mengenai mengajar (KBBI, 1990:13). Pembelajaran tidak hanya berpusat pada guru karena hakikatnya siswa yang lebih aktif. Dengan demikian, proses belajar mengajar perlu berorientasi pada kebutuhan dan kemampuan siswa. Pembelajaran harus dapat memberikan pengalaman belajar yang menyenangkan dan berguna bagi siswa. Guru 
perlu memberikan bermacam-macam situasi belajar yang memadai untuk materi yang disajikan dan guru perlu menyesuaikan dengan kemampuan dan karakteristik siswa, sehingga dapat menciptakan situasi komunikasi yang santun.

\section{SIMPULAN}

Bentuk kesantunan berbahasa terbagi dalam dua bentuk yakni bentuk kesantunan linguistis dan bentuk kesantunan pragmatis. Bentuk kesantunan linguistis antar siswa di SMA Negeri I Dulupi Kabupaten Boalemo dalam ragam resmi dan ragam pergaulan meliputi pilihan kata (diksi) yang tepat, intonasi, dan struktur kalimat yang menunjukkan kesantunan berbahasa. Bentuk kesantunan pragmatis dalam ragam resmi ditandai dengan penggunaan majas perumpamaan sedangkan dalam ragam pergaulan ditandai dengan penggunaan majas metonimia.

Kesantunan berbahasa di SMA Negeri 1

Dulupi Kabupaten Boalemo berdasarkan prinsip kesantuan Leech ditemukan beberapa maksim, yaitu: (1) maksim kebijaksanaan, (2) maksim kedermawanan, (3) maksim kesederhanaan, (4) maksim kesepakatan, dan (5) maksim kesimpatian. Sementara Pelanggaran maksim menurut prinsip kesantunan berbahasa menurut Leech yaitu maksim kebijaksanaan, maksim kedermawanan, dan maksim kesederhanaan.

Kesantunan berbahasa di SMA Negeri I Dulupi Kabupaten Boalemo didukung oleh beberapa faktor, yaitu faktor bahasa daerah Gorontalo, lingkungan sekolah, dan juga lingkungan keluarga atau tempat tinggal. Implementasi kesantunan berbahasa di SMA Negeri I Dulupi Kabupaten Boalemo dapat dilaksanakan dalam proses pembelajaran maupun dalam situasi informal di luar jam pelajaran.

\section{DAFTAR PUSTAKA}

Chaer, Abdul dan Leonie Agustina. 2004. Sosiolinguistik: Perkenalan Awal. Jakarta: Rineka Cipta.
Chaer, Abdul. 2010. Psikolinguistik: Kajian Teoritik. Bandung: Rineka Cipta.

Djajasudarma, F. T. 2012. Wacana dan Pragmatik. Bandung: Rafika Aditama.

Hamidah. 2017. Kesantunan Berbahasa sebagai Upaya Meraih Komunikasi yang Efektif. Arkhais

Keraf, Gorys. 2004. Komposisi Sebuah Pengantar Kemahiran Bahasa, Flores: Nusa Indah

Hasan, M. Iqbal, 2002. Pokok-pokok Materi Metodologi Penelitian dan Aplikasinya. Bogor: Penerbit Ghalia Indonesia.

Leech, Geofrey. 1993. Prinsip-prinsip Pragmatik. Jakarta: Universitas Indonesia (UI-Press).

Mahsun. 2005. Metode Penelitian Bahasa. Jakarta: Raja Grafindo Persada

Miles, Matthew B dan A. Michael Huberman. 1992. Analisis Data Kualitatif (diterjemahkan Tjejep Rohendi Rohadi). Jakarta: UI Press.

Poerwadarminta.1984. Bahasa Indonesia untuk Karang-Mengarang, Yogyakarta: UP Indonesia

Setiawan, H. dan Rois, S. 2017. Wujud Kesantunan Berbahasa Guru: Studi Kasus di SD Immersion Ponorogo. Jurnal Gramatika, 3 (2), 145-161.

Sumarsono dan Paina. 2002. Sosiolinguistik. Yogyakarta: Sabda

Pranowo. 2009. Berbahasa secara Santun. Yogyakarta: Pustaka Belajar.

Rahardi, Kunjana. 2009. Sosiopragmatik. Jakarta: Penerbit Erlangga. 
Sugiyono, 2007. Metode Penelitian Pendidikan Pendekatan Kuantitatif, kualitatif, dan $R \& D$. Bandung: Alfabeta

Moleong, Lexy J. 2000. Metodologi Penelitian Kualitatif. Bandung: PT. Remaja Rosdakarya

Widjono Hs. 2005. Bahasa Indonesia Mata Kuliah Pengembangkan Kepribadian di Perguruan Tinggi. Jakarta: PT. Grasindo. 